\title{
Perancangan Game "IM HERE" Berbasis Augmented Reality dan Location Based Sebagai Media Promosi
}

\author{
Arief Kurniawan Yoga Dywa ${ }^{1}$, RB. Hendri Kuswantoro ${ }^{2}$ \\ ${ }^{1}$ Sekolah Tinggi Multi Media Yogyakarta \\ ariefkyd12@gmail.com \\ ${ }^{2}$ Sekolah Tinggi Multi Media Yogyakarta \\ rbhendrikuswantoro@gmail.com
}

\begin{abstract}
Abstrak
Dalam bisnis perlu adanya iklan untuk mempromosikan produk berupa barang, jasa hingga tempat wisata. Kegiatan promosi sudah berkembang yang pada awalnya dari mulut kemulut hingga pada penggunaan teknologi. Teknologi yang digunakan pada kegiatan promosi dapat berupa televisi, web dan media sosial. Salah satu media baru yang digunakan sebagai media promosi adalah game. Game sebagai media promosi digunakan dengan memasang iklan pada game melalui sistem promote dan monetizing. Pelaku bisnis besar menggunakan fitur augmented reality dan location based yang termasuk teknologi baru dalam game sebagai fitur yang memiliki tujuan untuk memikat calon konsumen. Teknologi augmented reality merupakan teknologi yang menggabungkan gambar dunia nyata dan objek dunia maya sedangkan location base merupakan teknologi yang mendeteksi lokasi pengguna. Implementasi augmented reality dan location base pada game dapat dibuat menggunakan Unity $3 D$ yaitu dengan mengakses fitur kamera dan gps melalui algoritma Unity $3 D$. Location base diimplementasikan pada gameplay untuk mendeteksi lokasi pemain sehingga jika pelaku bisnis berkehendak untuk menjadikan lokasinya sebagai titik promosi dapat terbaca dan dieksekusi oleh algoritma untuk memberikan keuntungan bagi pengguna atau calon konsumen. Penggunaan fitur kedua teknologi tersebut pada gameplay suatu game yang ditujukan sebagai media promosi dapat memberikan nuansa baru bagi calon konsumen untuk berinteraksi dengan produk sehingga calon konsumen tertarik.
\end{abstract}

Kata Kunci : Augmented reality, location based, media promosi.

\section{"IM HERE" Game Design Based on Augmented Reality and Location Based as a Promotional Media}

\begin{abstract}
On a business there must be advertise for a product, services, and also for entertainment. Advertisement activities has been changed from door to door advertisement to technological advertisement. Technology that used for advertisement are televisions, web and social media. One of the new technology and media that use for advertisement are games. Games as advertisement tool use ads via monetizing and promote services. Some company use augmented reality and location based technology which new technology as advertisement enhancement to attract costumer. Augmented reality is technology that combine real world object and game object, and location based is technology that determine user location in the point of world as coordinate or place descriptions. Augmented reality and location based can be implemented using Unity3D algorithm through accessing user camera and gps. Location based can be implemented as marker for some feature to active if company that want advertise their product or place, user must get profit from activating the feature. Using augmented reality and location base as gameplay may give new experience for user and attract new user or customer.
\end{abstract}

Keyword : Augmented reality, location based, promotional media. 


\section{Pendahuluan}

Promosi atau iklan merupakan akivitas badan usaha yang menawarkan produk atau jasa baik secara langsung maupun secara digital. Pada era globalisasi dan revolusi industri 4.0 ini salah satu jalan penayangan iklan adalah melalui media informasi seperti televisi, radio, selebaran atau poster, koran, laman internet, hingga aplikasi pada smartphone. Sekarang bisnis juga mulai merambah pada aplikasi berbasis daring sosial seperti, WhatsApp, Line, Twitter dan Instagram. Pada daring sosial ini pedagang atau pengusaha menjual produk ataupun jasa mereka dengan foto yang menarik dan kalimat yang persuasif sehingga pengguna daring sosial dapat bertanya langsung atau membeli jika sesuai dengan seleranya. Media sosial dan aplikasi lain merupakan salah satu jenis media baru, menurut Watie (2012) Media seperti televisi, radio, majalah, koran digolongkan menjadi media lama/ old media, dan media internet yang mengandung muatan interaktif digolongkan sebagai media baru/ new media.Agensi lokasi wisata juga dapat menawarkan paket wisata dan lokasi wisata melalui jejaring sosial. Dalam praktiknya pengguna jejaring sosial yang menggunakan produk, jasa dan lokasi wisata, sering mengunggah foto pada jejaring sosial dengan caption yang sesuai dengan produk, jasa maupun tempat wisata yang mereka gunakan atau nikmati.

Indonesia merupakan negeri dengan budaya yang majemuk. Pada setiap daerah memiliki corak budaya masing-masing. Salah satu budaya yang masih dipertahankan adalah budaya tahayul atau budaya mistis. Budaya mistis adalah kepercayaan terhadap sesuatu yang bersifat abstrak namun tetap diyakini secara turun-temurun seperti percaya pada adanya hantu dan makhluk gaib. Manusia Jawa memandang hantu sebagai dunia lain. Yakni, dunia supranatural yang misterius. Keganjilan makhluk hantu ini disebabkan dia bisa melihat manusia, dan manusia tidak bisa melihat hantu secara langsung. Hanya orang-orang tertentu yang diberi kelebihan dalam hal-hal gaib, yang mampu melihat hantu (Suwardi, 2007). Karena budaya mistis masih dipertahankan mengakibatakan berkembangnya sektor wisata yang diyakini sebagai wisata bernuansa mistis atau sektor wisata yang memiliki tema horor atau mistsis. Pada sektor wisata di Indonesia, terdapat wisata yang bernuansa mistik seperti tempat yang dianggap angker dan berhantu. Selain itu rumah hantu merupakan tempat wisata dimana wisatawan dapat menguji keberanian. Rumah hantu sering hadir dalam pasar malam bahkan sudah menjadi suatu tradisi di pasar malam atau theme park untuk 
mengadakan satu rumah hantu. Adanya wisata bernuansa mistis menarik banyak wisatawan untuk berkunjung (Suwardi, 2007). Di Indonesia rumah hantu merupakan wahana yang wajib saat diadakannya taman karnaval.

Selain dari wahana bernuansa mistis, di Karanganyar terdapat restoran yang memiliki tema mistis atau horor. Kampung Halloween merupakan restoran yang terletak di Bukit Sekipan, Tawangmangu. Pada restoran tersebut manekin dirias dengan rias menyeramkan seperti penggambaran makhluk halus yang dikenal di Indonesia, selain itu juga musik yang dialunkan menambah nuansa horor. Di Kampung Halloween juga terdapat rumah hantu, dimana pengunjung saat keluar dapat memilih untuk melewati rumah hantu atau jalan keluar biasa. Dengan dekorasi yang bertema horror dan wahana rumah hantu menjadikan Kampung Halloween sebagai tempat yang menarik untuk berswafoto atau membuat video kreatif. Wahana rumah hantu memiliki pencahayaan yang redup dan cenderung gelap, oleh karena pengunjung yang akan berswafoto atau membuat video kreatif akan mengalami kesulitan dalam pencahayaan karena pencahayaan ruangan yang gelap dan pencahayaan pada kamera gawai tidak memiliki intensitas yang tinggi. Sehingga pengunjung dapat meningkatkan pengalaman bermain di wahana rumah hantu dengan bermain game berbasis Augmented Reality, karena game berbasis Augmented Reality menggunakan kamera pengunjung untuk menggambarkan suasana ruangan dengan menambahkan komponen seperti efek suara dan objek yang meningkatakan suasana horror yang sudah terbentuk. Teknologi Location Detection juga digunakan sebagai promosi dari lokasi Kampung Halloween. Teknologi Location Detection digunakan untuk menunjukan posisi pemain dan memasang titik bermain yaitu Kampung Halloween, tepatnya pada wahana rumah hantu. Sehingga calon konsumen dan calon pengunjung akan tertarik untuk berkunjung menuju titik tersebut untuk bermain dan mengunjungi Kampung Halloween.

Pengaplikasian game di Indonesia sebagai media promosi sudah dilakukan oleh berbagai developer game. Game yang diproduksi dapat memuat konten lokal sehingga pemain dapat tertarik untuk bermain. Salah satu konten yang dapat ditawarkan yaitu kebudayaan Indonesia yang masih mempercayai tahayul seperti dukun, alam ghaib dan benda mistis. Game yang menawarkan hal tersebut antara lain 
DreadOut, DreadOut VR, dan Man Of Medan. Game tersebut merupakan game berplatform $P C$, sehingga memerlukan alat yang tidak fleksibel dan dapat dimainkan tempat lain. Selain dari kekurangan fleksibilitas, kekurangan lainnya terdapat pada suasana game yang terkadang kurang terbangun karena hanya bermain di depan komputer.

Penggunaan $V R$ atau virtual relity dapat meningkatkan ketegangan dalam bermain namun berkendala pada masalah mobilitas pemain. Namun dengan smartphone pemain dapat memainkan lebih leluasa karena mobilitas smartphone yang tinggi. Mobilitas penggunaan augmented reality dan location based dapat membangun suasana yang lebih realistis sehingga pemain dapat bermain di tempat yang angker atau mistis. Menurut Mustaqin (2017), Kelebihan dari Augmented reality adalah sebagai berikut : lebih interaktif, efektif dalam penggunaan, dapat diimplementasikan secara luas dalam berbagai media, modeling obyek yang yang sederhana, karena hanya menampil kanbeberapa obyek, pembuatan yang tidak memakan terlalu banyak biaya, mudah untuk dioperasikan.

Pemaanfaatan Augmented reality (AR) pada pembuatan game adalah untuk menggabungkan dunia maya dengan dunia nyata dengan alat pendukung kamera, menurut Rickman Roedavan dalam bukunya Unity Tutorial Game Engine (2015). Sedangkan Location based merupakan teknik untuk mengetahui posisi dari pemain atau pengguna gim atau gadget melalui perangkat terpasang Global Positioning System (GPS). GPS adalah sistem untuk menentukan posisi dan navigasi secara menyeluruh dengan menggunakan media satelit dan metode Triangulasi. (Susilo, 2014).

Berdasarkan potensi yang ada gim "I'm Here" berbasis Augmented Reality (AR), dan Location Based Games diproduksi dengan bertujuan untuk mempromosikan rumah hantu khususnya Kampung Halloween, Bukit Sekipan dengan mengaplikasikan teknologi Augmented Reality dan Location Based sebagai media baru untuk memberi kesan baru bagi calon konsumen. 


\section{Hasil dan Pembahasan}

Salah satu cara pengembangan sebuah aplikasi yakni metode waterfall. Metode ini juga dapat di gunakan dalam produksi game dengan mengikuti prosedur mulai dari perancangan konsep, analisis, pemrogramman dan produksi hingga pengujian (Bates, 2004 hal. 250).

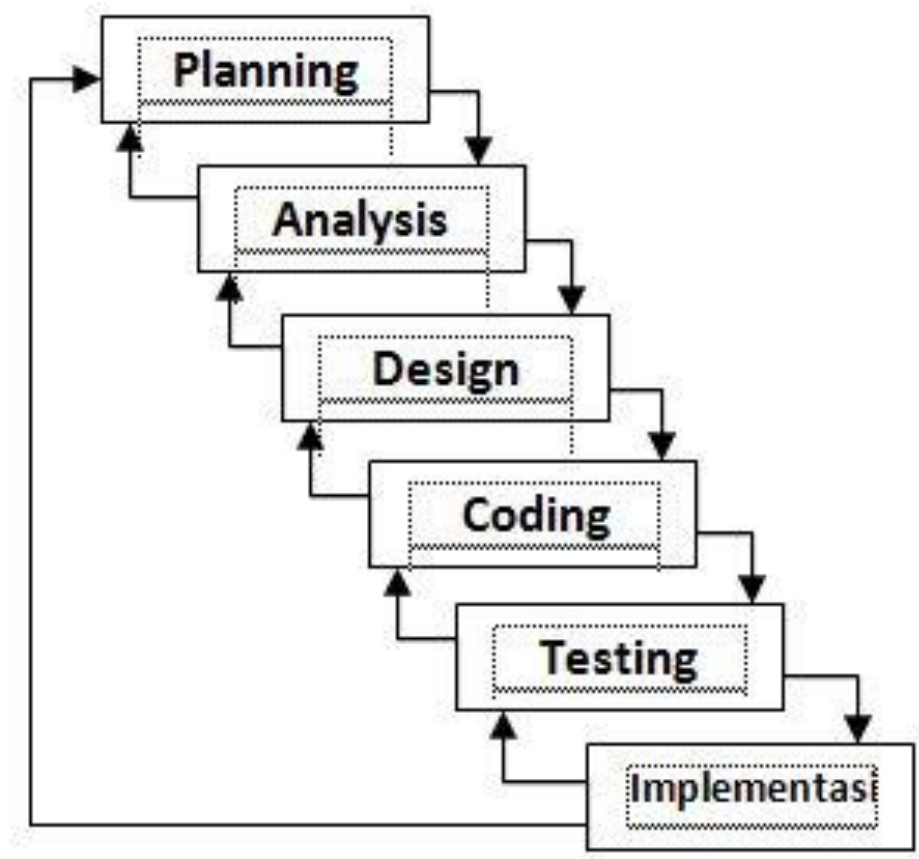

Gambar 1. Metode Waterfall

Bahan, Media dan Peralatan yang digunakan adalah sebagai berikut:

a. Media/Platform

Melihat pengguna gawai genggam seperti smartphone semakin banyak dan tujuan utama dari gim "Im Here" adalah sebagai media promosi dengan Augmented reality dan Location based maka produksi gim "Im Here" akan ber-platform mobile android.

b. Peralatan Software

Berikut adalah beberapa software yang digunakan untuk mengembangkan gim "Im Here": 
1) Dalam pembuatan aset dua dimensi dapat digunakan berbagai macam software seperti CorelDraw, Photoshop, hingga Gimp. Namun pada praktiknya beberapa software memiliki tingkat kesesuaian pada jenis aset tertentu. Oleh karena itu pada proses produksi gim "Im Here” akan menggunakan CorelDraw sebagai software pembuatan $U I$ dan $U X$ yang berbasis vektor.

2) Pembuatan aset tiga dimensi menggunakan Blender 3D yang merupakan software pembuat objek tiga dimensi open source dengan spesifikasi keunggulan pada tipe objek Hardsurface atau lowpoly, sehingga ringan saat dimainkan di smartphone.

3) Untuk game engine, menggunakan Unity $3 D$ karena software tersebut memiliki banyak dokumentasi apabila terjadi kendala saat proses produksi.

Dalam produksi game "I'm Here" berbasis Augmented Reality (AR), dan Location Based Games dibatasi sebagai game dengan tujuan untuk mempromosikan rumah hantu khususnya Kampung Halloween, Bukit Sekipan dengan mengaplikasikan teknologi Augmented Reality dan Location Based menggunakan algoritma pembacaan koordinat pemain.

\section{Konsep}

Tahap konsep merupakan tahap dalam menentukan rancangan game mulai dari konsep gameplay, art, sound, dan tujuan dari pembuatan game yang digunakan sebagai pedoman selama produksi. Berikut deskripsi konsep game yang akan dirancang:

a. Judul

Game "I'm Here" berbasis augmented reality dan location based sebagai media promosi.

b. Target audience

Target audience game yang disarankan adalah remaja menurut sistem rating Indonesia Game Rating System (IGRS) khususnya pengguna smartphone android

c. Tujuan

Tujuan produksi game adalah mengimplementasikan augmented reality dan location based dalam game sebagai media promosi. Dan memberikan 
pengalaman baru pada calon konsumen, user atau player dalam berinteraksi dengan iklan atau media promosi.

d. Genre game

Genre game yang diproduksi adalah first person shooter (FPS), horror, survival, augmented reality $(A R)$ dan location based. Digunakannya $A R$ dan sudut pandang orang pertama (FPS) adalah untuk membangun suasana horor yang lebih baik serta dapat digunakan sebagai media foto.

e. Asset game

Asset game yang diproduksi adalah aset 2D yang diproduksi dengan menggunakan corel, Sai, dan Photoshop. Aset 3D yang diproduksi dengan menggunakan Blender 3D. Aset sound akan didapat melalui web dengan lisensi gratis atau free license.

f. Software yang digunakan

Software yang digunakan untuk pemrogramman, penyatuan aset dan produksi adalah Unity $3 D$.

\section{Desain dan Analisis}

Pada tahap desain dan analisis penulis atau pengembang melakukan analisis dari konsep yang telah ada dan mendesain game. Pada tahap ini analisis akan dilakukan setiap ada penambahan fitur dan apabila desain tidak sesuai maka akan dilakukan desain ulang sehingga mencapai tujuan atau selaras dengan konsep yang ada. Melalui analisis dan desain didapatkan hasil sebagai berikut:

\section{Implementasi Konsep}

Latar belakang game "Im Here." adalah lokasi dimana pemain bermain. Karena penggunaan fitur kamera dan augmented reality membuat penggambaran latar belakang didapat dari gambar yang ditangkap oleh kamera gawai ditambah objek maya dari gim. Augmented reality merupakan teknologi interaktif yang menggabungkan dunia maya dan dunia nyata melalui kamera. Penggunaan teknologi augmented reality pada game "I'm Here!" ditujukan untuk mendapatkan nuansa bermain baru pada pemain dalam bermain game horor. 
Banyak game horor yang diproduksi oleh developer namun baru sedikit yang menggunakan teknologi augmented reality.

Penggabungan teknologi location detection dan augmented reality dapat dijadikan sebagai rujukan untuk media promosi suatu objek. Hal ini karena dengan location detection maka pemain diharuskan berada diarea yang telah ditentukan yaitu area Kampung Halloween untuk mendapatkan tambahan drop chance items sebagai keuntungannya. Pemain dapat bermain game yang bernuansa horor yang satu tema dengan Kampung Halloween yang merupakan restoran bertema horor. Sehingga pemain mendapatkan nuansa yang lebih terbangun daripada bermain di area yang memiliki nuansa yang berbeda dengan game ini. Pada photo session pemain dapat berfoto dengan memanfaatkan teknologi augmented reality untuk dipublikasikan pada sosial media sebagai media promosi tidak langsung oleh pemain.

\section{Gameplay}

Gim “Im Here.” memiliki konsep arcade survival. Pemain akan bermain sudut pandang orang pertama (First Person) untuk mengalahkan musuh yang ada dengan menekan layar gawai. Dalam permainan ini pemain akan diberikan nyawa sebanyak yang telah ditentukan. Pemain juga dapat membeli peralatan untuk alat bantu dalam bermain.

Pemain diminta untuk menembak musuh dengan mengarahkan gadget kearah target atau musuh dan menekan layar gawai. Setiap musuh memiliki nyawa berbeda-beda dan semakin lama pemain bermain atau dalam kondisi survive, maka musuh akan semakin sulit dengan pergerakan yang lebih cepat atau nyawa yang lebih banyak. Tingkat kesulitan musuh akan naik setiap satu setengah menit sekali dimana satu kumpulan musuh pada jeda waktu tersebut disebut dengan Wave, sehingga player dengan waktu survive tinggi akan menghadapi Wave musuh yang lebih kuat. Pada setiap pemain mengalahkan musuh akan memberi peluang untuk mendapatkan items. Items ini berguna untuk memudahkan permainan berikutnya apabila dipasangkan. Jika pemain berada di tempat yang telah ditentukan yaitu Kampung Halloween, maka pemain akan mendapatkan bonus drop chance items lebih besar dari pada jika bermain di luar area Kampung Halloween. 
Tujuan pemain adalah dapat hidup dengan lebih lama dan mendapatkan skor tertinggi dengan serangan dari musuh yang lebih kuat secara progresif. Saat kondisi bermain pemain mendapatkan waktu jeda selama tiga puluh detik di setiap satu setengah menit untuk mengatur siasat, menggunakan alat bantu seperti obat atau alat untuk memperkuat serangan dan daya tahan.

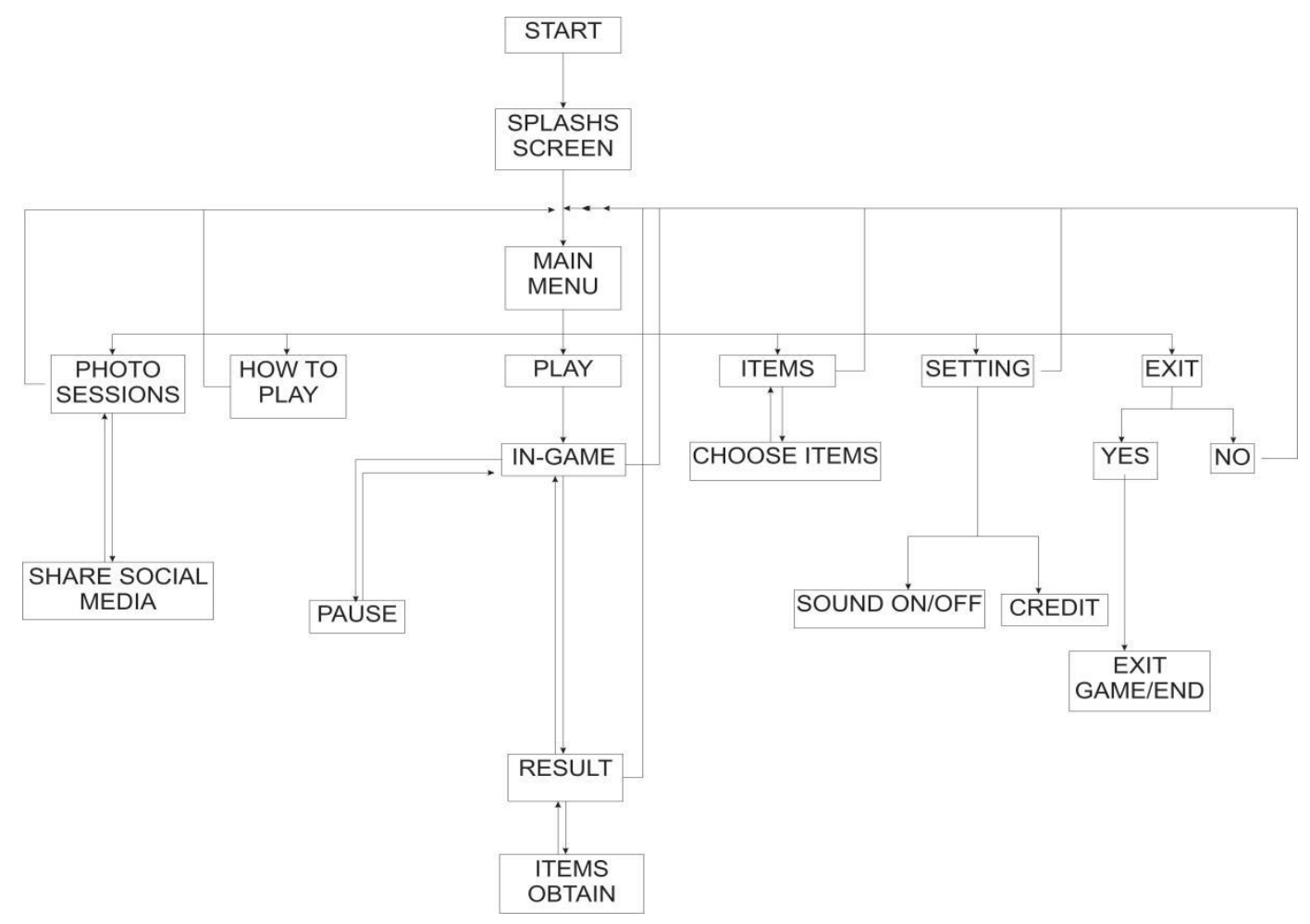

Gambar 2. Desain Rancangan Flowchart Game "Im Here"

Flowchart tersebut di rancang sesuai konsep gim “Im Here.” dimulai dari splash screen hingga akhir game. Pada game ini pemain dapat langsung bermain dengan menekan tombol play. Jika pemain berada di lokasi yang telah ditentukan yaitu Kampung Halloween maka pemain akan mendapatkan keuntungan yaitu bonus drop chance items yang digunakan sebagai keuntungan yang ditawarkan. Berdasarkan flowchar maka berikut desain interface pada game "I'm Here": 


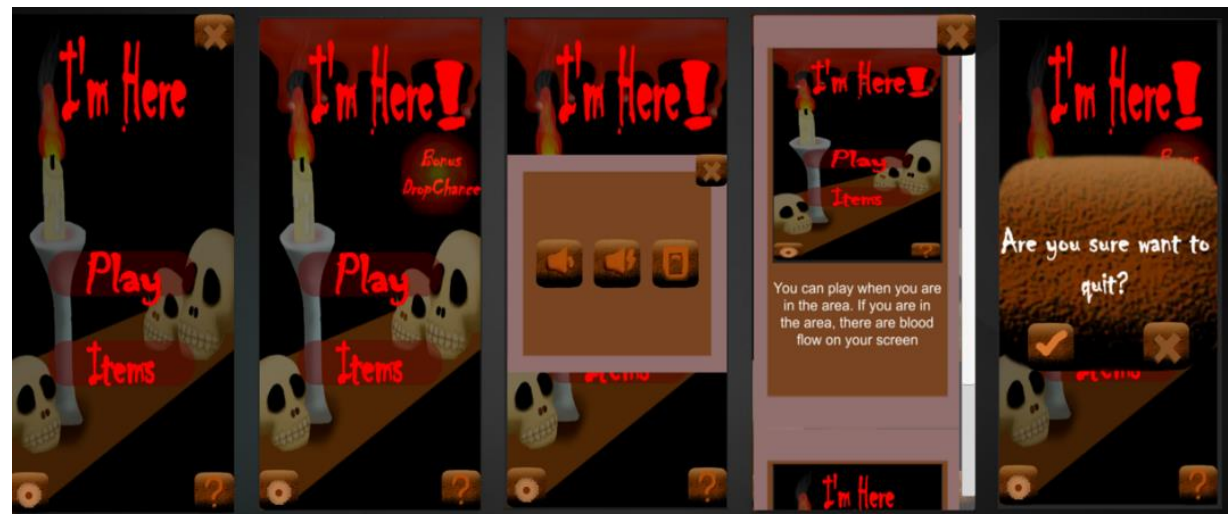

Gambar 3. Desain interface main menu

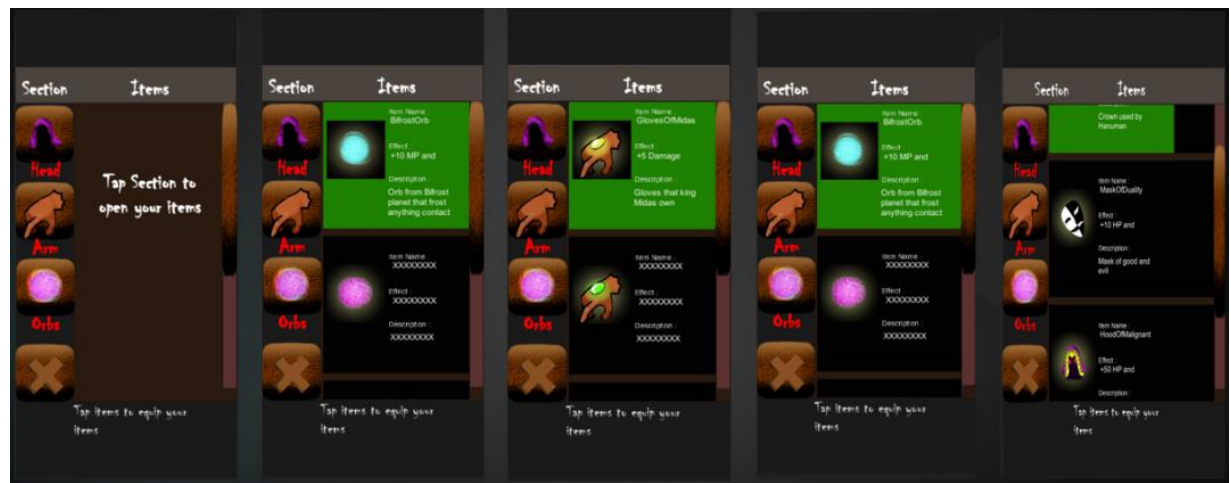

Gambar 4. Desain interface Inventory

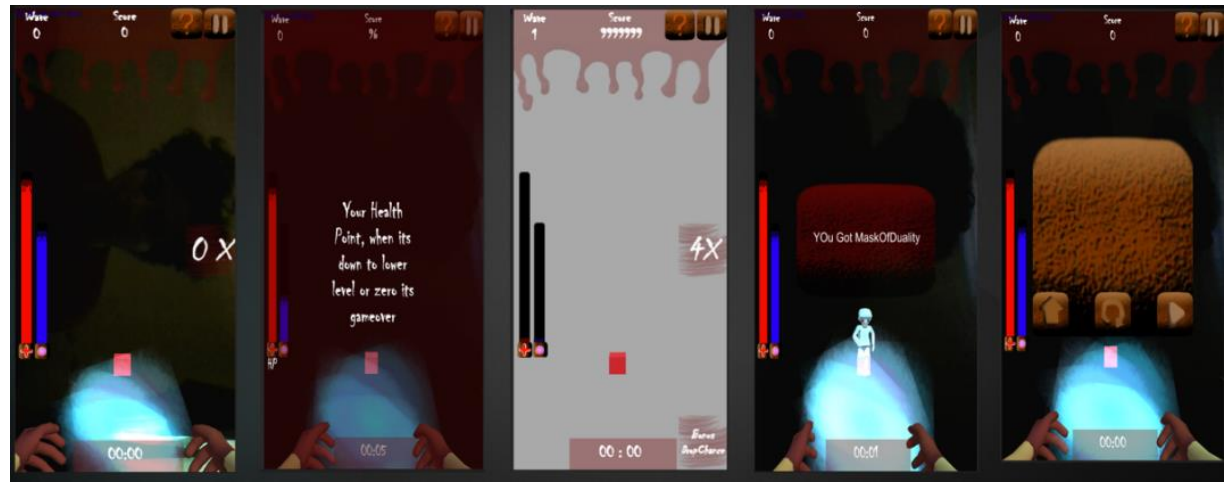

Gambar 5. Desain interface in-game 


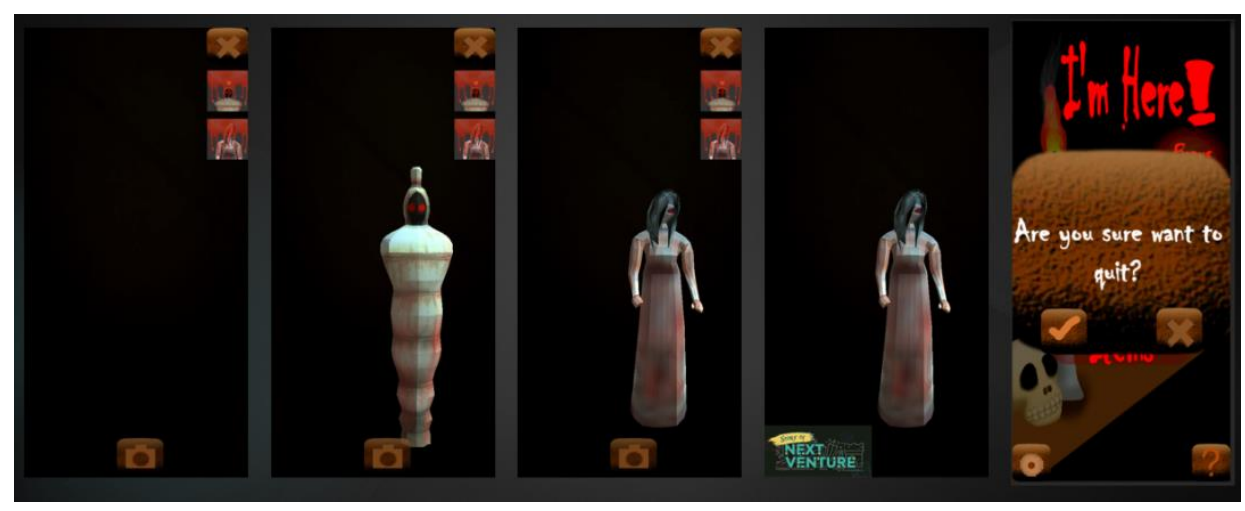

Gambar 6. Desain interface photo seisson

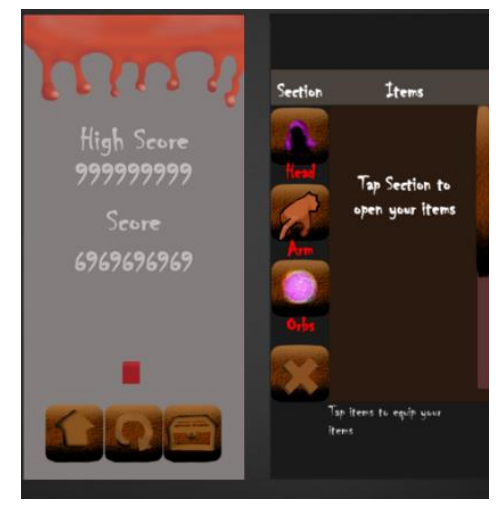

Gambar 7. Desain interface result

3. Musuh

Gim "Im Here” merupakan gim horor AR dan menggunakan fitur lokasi, seiring dengan tujuan awal yaitu untuk media promosi lokasi wisata Kampung Halloween yang bernuansa horor maka gim “Im Here” menampilkan objek musuh yaitu hantu lokal Indonesia seperti pocong, tuyul dan kuntilanak.

Tujuan menampilkan hantu lokal Indonesia adalah selain dari target utama sebagai media promosi yang mempromosikan tempat sekaligus budaya, tujuan lainnya adalah untuk membangun suasana pemain saat bermain di area Kampung Halloween yang didalamnya terdapat figur hantu lokal seperti pocong kuntilanak dan tuyul sebagai ornamen hiasan dan adanya wahana rumah hantu. 


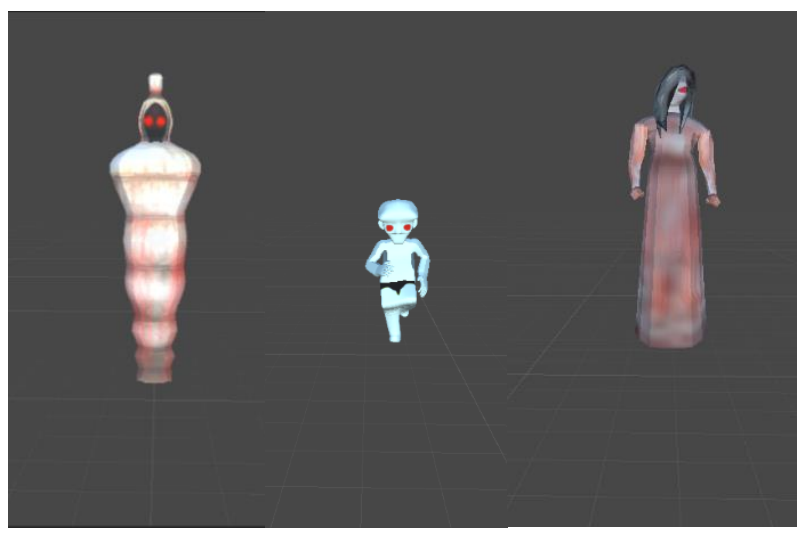

Gambar 8. Karakter

Hasil dari perancangan adalah sebagai berikut:

1. Praproduksi

Pada tahap praproduksi, menyiapkan kerangka yang diperlukan dalam pembuatan gim. Selain itu juga menuliskan mengenai persiapan yang perlu disiapkan dan dikuasai sebelum memulai produksi. Kemudian melakukan brainstorming dengan konsep yang disiapkan sehingga target atau tujuan dari gim yang akan diproduksi jelas.

Setelah melalui brainstorming kemudian melakukan riset lokasi atau wahana wisata yang dipromosikan dan pendekatan yang sesuai untuk mempromosikannya. Lokasi yang digunakan dalam game adalah Kampung Halloween di Bukit Sekipan, Tawangmangu.

Setelah menentukan lokasi, kemudian mencari referensi gim yang akan digunakan sebagai acuan gameplay untuk gim yang akan diproduksi. Pokemon Go dengan sudut pandang orang pertama pada gim Skyrim menjadi acuan untuk mengeksekusi gim yang akan diproduksi. Karena lokasi yang diangkat adalah lokasi wisata bertema horor maka gameplay akan menyesuaikan dengan bernuansa horor seperti mengangkat ambient horor, hantu atau makhluk halus Indonesia dan dukun. 
Setelah dirasa cukup untuk acuan gameplay dan target promosi, kemudian membuat daftar aset yang harus dikerjakan dan membuat GDD atau Game Design Document yang berisi seluruh konsep game, gameplay dan aset aset.

Setelah membuat $G D D$, kemudian membuat prototype untuk uji coba apakah dengan fitur yang digunakan pemain dapat bermain dengan nyaman dan apakah gim yang diproduksi berjalan dengan baik.

2. Produksi

Pada tahap produksi. semua aset dan mekanik yang akan dibuat harus diawasi dan disesuaikan dengan $G D D$ yang telah dibuat. Apabila terdapat perubahan pada $G D D$ maka perubahan pada aset dan mikanik gim juga dapat terjadi. Pembagian susunan pekerjaan dibagi sebagai berikut :

a. Visual

Pada tahap ini akan dibuat aset visual seperti user interface, background, logo, layout, aset tiga dimensi untuk musuh dan karakter, dan ikon gim.

\section{b. Audio}

Pada jobdesk ini akan dibuat audio seperti sound effect, Backgorund Music, dan Ambient. Apabila pembuatan audio mengalami kendala yang sukar diatasi maka jalan keluar yang diambil adalah mencari audio dengan membeli audio dengan lisesnsi atau mengunduh audio lisensi tidak berbayar. Audio didapat dari web freesound.com dengan lisensi tidak berbayar.

\section{c. Pemrogramman}

Pada tahap akan dibuat prototyupe dan mencoba memasukan dummy aset untuk melakukan penyesuaian terhadap gim yang dikembangkan. Apabila sudah terpenuhi selarasan mekanik dan gaya seninya maka langkah selanjutnya adalah memperkuat mekanik gim sehingga dapat sesuai dengan GDD. Selanjutnya memasukkan aset visual, audio dan aset lain dalam game sesuai GDD dan perancangan sebelumnya. Pada tahap ini penggunaan fitur augmented reality dibuat dengan menggunakan inputan kamera melalui script webcamerascript.cs 
yang berisi tentang alogaritma pembaca kamera pada gawai. Metode yang dipakai untuk mendapatkan gambar dari kamera adalah Unity WebCameraTexture yang ada pada scripting refrence Unity3d. sementara untuk fitur pembaca lokasi menggunakan input.Locations pada Unity3D. Penggunaan input.location digunakan untuk mendapatkan koordinat pemaindan mencocokan dengan koordinat Kampung Halloween dengan lingkup 10 meter dari titik tengah Kampung Halloween. Apabila pemain berada di area tersebut maka mekanik bonus akan muncul dan pemain akan mendapatkan bonus selama bermain di area tersebut.

\section{Pascaproduksi}

Pada tahap pascaproduksi dilakukan pengujian gim dengan tujuan untuk mencari kesalahan yang ada pada gim sehingga dapat dilakukan perbaikan sesuai dengan masalah yang ada. Berikut tahapan yang dilakukan :

\section{a. Alpha Testing}

Alpha testing dilakukan setelah gim selesai dikerjakan dengan catatan semua aset sudah diimplementasikan pada gim. Alpha testing dilakukan oleh pengguna untuk mencari kecacatan atau kesalahan dalam gim seperti dalam aturan main, pengaturan, tingkah laku musuh dan keseuaian dari aset sebagai pendukung dalam gim. Apabila terjadi kesalahan atau kecacatan maka kesalahan tersebut akan diperbaiki. Setelah gim dirasa bersih dari kesalahan dan sesuai dengan GDD maka gim akan diunggah ke GooglePlay store dan menjadikan versi closed alpha.

\section{b. Publish Closed Alpha}

Pada tahap Closed Alpha gim dipublikasikan ke GooglePlay Store dengan bendera Closed Alpha dengan tujuan untuk mendapatkan tayang iklan banner dan video. Selain pengujian iklan tahap Closed Alpha juga bertujuan agar gim dapat diunduh oleh pengguna lain.

\section{c. Beta Testing}

Beta testing dilakukan untuk mencari kesalahan pada gim dengan bantuan dari pengunduh aplikasi atau masyarakat. Hal ini dilakukan untuk mendapatkan masukan 
dari pengguna agar gim dapat berkembang dan sesuai dengan perminataan pasar atau klien.

\section{d. Monetizing}

Monetizing dilakukan untuk mengawasi alur iklan, alur pengguna, statistic pengguna, dan unpan balik pengguna pada gim yang sudah diunggah ke GooglePlay Store. Sehingga dapat dilakukan pembaharuan untuk kedepannya.

\section{Kesimpulan}

Game "I'm Here!" merupakan game berkatagori survival, augmented reality, dan location based dengan tema horor yang ditujuan sebagai media promosi Kampung Halloween di Bukit Sekipan, Karanganyar. Berdasarkan pembahasan di atas maka kesimpulan yang terkait dengan game "I'm Here!" meliputi :

Penerapan teknologi augmented reality pada game dapat menambah gaya bermain baru dan pengalaman bermain baru bagi pemain. Penerapan teknologi augmented reality dapat dilakukan dengan mengakses fitur kamera pada gawai sebagai latar belakang untuk game object. Teknologi location based digunakan sebagai titik kondisi fitur bonus pada game "I'm Here" aktif. Pada pengaplikasiannya teknologi location based menggunakan fungsi algoritma Unity yaitu Input.Location.

Fitur bonus pada gameplay dapat digunakan sebagai langkah promosi untuk suatu produk, jasa maupun tempat wisata. Dengan menggunakan fitur bonus, maka pemain akan tertarik untuk mendapatkan keuntungan dalam permainan sehingga lokasi Kampung Halloween yang digunakan sebagai area untuk mengaktifkan bonus dapat dipromosikan.

Berdasarkan pada pembahasan pada tahapan hingga akhir produksi game yang selanjutnya akan dibuat dengan menggunkan google API namun google API merupakan API berbayar maka untuk alternative lain dapat menggunakan mapboxsehingga mendapatkan lokasi yang lebih akurat dan tepat, penggunaan leaderboard google sehingga menarik pemain baru dan menggunakan alogaritma rendering kamera yang baru sehingga hasil gambar yang didapat akan lebih jernih. 
Game merupakan sebuah media baru yang fleksibel dan memiliki potensi yang luas. Sehingga dalam inovasi pembuatan game tidak hanya difokuskan kepada unsur edukasi namun juga sebagai media promosi, media komunikasi dan media lain. Akan lebih baik jika tidak membatasi dengan ide inovatif dan kreatif untuk sebuah game, dengan syarat tidak melanggar norma dan etika yang ada pada tujuan akhir pengembangan game, sehingga akan tercipta game baru yang lebih inovatif, kreatif dan tepat sasaran.

\section{Referensi}

Bates, B. 2004. Game Design Second Edition. Boston : Thomson Course Technology PTR.

Roedavan, R. 2015. Unity Tutorial Game Engine. Bandung : Informatika Bandung.

Susilo, Y.S., dkk. Sistem Pelacakan Dan Pengamanan Kendaraan Berbasis GPS Dengan Menggunakan Komunikasi GPRS. Jurnal Ilmiah Widya Teknik, Vol . 13, No 1, 2014.

Suwardi. Dunia Hantu, Mistik Dan Wisata Spiritual Di Pesisir Selatan. Jurnal Humaniora, vol 12 no.1 / April 2007.

Watie, E.D.S. PERIKLANAN DALAM MEDIA BARU (Advertising In The New Media ). THE MESSENGER, Volume IV, Nomor 1, Edisi Januari 2012. 